\title{
Canonización o fiesta nacional: la celebración de Felipe de Jesús en México, 1797-1833
}

\section{Canonization or National Holiday: The Celebration of St. Philip of Jesus in Mexico, 1797-1833}

\author{
David Carbajal López \\ Centro Universitario de los Lagos \\ Universidad de Guadalajara, México \\ ORCID: 0000-0002-3182-6599 \\ davidclopez@hotmail.com
}

Resumen: La fiesta del beato Felipe de Jesús a principios del siglo xIx permite analizar las transformaciones de los eventos festivos corporativos en el marco del proceso de secularización del antiguo régimen al orden liberal moderno. El análisis de expedientes judiciales, actas, periódicos e impresos nos muestra las implicaciones de la crítica ilustrada y la opinión pública. Primero, en la recaudación de recursos con la deslegitimación de la limosna por el principio de la libre voluntad; segundo, en la imagen del beato, convertido en protomártir nacional por el intento de los liberales de apropiarse de la fiesta a pesar de las críticas de los más radicales. Tercero, en los mensajes religiosos: la fiesta servía inicialmente para la corrección de las costumbres y como ejemplo para la conversión, mas hacia mediados del siglo se estimará a Felipe de Jesús como protector de sus compatriotas.

Palabras clave: fiestas; ceremonias; catolicismo ilustrado; limosnas; secularización. 
Abstract: The feast of the Blessed Philip of Jesus in the early 19th century makes it possible to analyze the transformations of corporate festive events within the framework of the secularization of the ancien régime to modern liberal order. An analysis of court records, records, reports and printed matter reveals the implications of enlightened criticism and public opinion. First, in the collection of resources following the delegitimization of almsgiving on the basis of the principle of free will; second, in the image of the saint, converted into a national protomartyr by the liberals' attempt to appropriate the feast despite criticism from more radical elements. Third, in the religious messages: the feast originally served to correct customs and as an example for conversion, yet by the middle of the century, Philip of Jesus came to be regarded as a protector of his compatriots.

Key words: feasts; ceremonies; enlightened catholicism; alms; secularization.

Fecha de recepción: 18 de julio de 2016 Fecha de aceptación: 26 de septiembre de 2016

$\mathrm{L}$ a celebración del protomártir mexicano Felipe de Jesús, ${ }^{1}$ en la ciudad de México, comenzó en el siglo xVII bajo la responsabilidad del Ayuntamiento de la capital y los frailes franciscanos. Desde 1629 se recuerda al ya beato con rito de primera clase y función con asistencia de la corporación municipal en el convento franciscano. Era pues una fiesta del público de la capital, que permitía celebrar no sólo la llegada al cielo de uno de sus hijos, sino además la posición de la ciudad en el mundo católico (Conover, 2011; Zárate, 2002, pp. 358-359 y 362). En la catedral, la celebración comenzó hasta 1636, y a partir de 1682 se inició la costumbre de que las comunidades franciscanas llevaran en procesión la imagen del beato desde la víspera (García, 1904, p. 305; Marroquí, 1903, pp. 425-426). Se sumó así a la larga lista de celebraciones en que se desplegaba, no sólo el fervor religioso, sino también la actividad política en una monarquía cuya legitimidad estaba fundada en su

${ }^{1}$ Lego franciscano descalzo nacido en la ciudad de México hacia 1572 en el seno de una familia dedicada al comercio. Aunque habría tenido una primera etapa de vida religiosa en Puebla a partir de los 16 años, dejó el hábito para dedicarse a la platería y luego al comercio. Enviado por su familia a Manila, fue ahí donde profesó por segunda vez, de nuevo con los franciscanos, fue crucificado en Japón en febrero de 1597, a donde había llegado a fines del año anterior porque una tempestad desvió su embarcación que se dirigía a Acapulco (Zárate, 2002, pp. 357-358; Conover, 2011, pp. 444-448).

\section{()(1) $\$$}


papel protector del catolicismo. Los rituales, gestos y cortesías eclesiásticas eran fundamentales para establecer la autoridad de los magistrados, urbanos en este caso, frente al clero de la época (Cañeque, 2004).

Aunque la memoria del mártir tuvo altibajos con el paso de los años, en la segunda mitad del siglo XVIII hubo intentos de darle mayor realce a la celebración. Ya en 1777 se comenzaron las gestiones para que contara con oficio propio y su rito se extendiera a las diócesis sufragáneas, como se obtuvo en efecto en $1779 .{ }^{2}$ En 1786, el Ayuntamiento solicitó la cooperación del Cabildo catedralicio para la fiesta y también en la causa de canonización. Fue entonces que se nombraron como comisionados a los canónigos Juan José Gamboa y José Patricio Fernández de Uribe, cuya muerte de este último en 1796 provocaría su reemplazo por el medio racionero Joaquín José Ladrón de Guevara. ${ }^{3}$ En este artículo vamos a referirnos a la fiesta justo en la época de su gestión, culminada con su muerte en 1833 .

En realidad se trata de un tema ya abordado por la historiografía mexicanista. La fiesta fue motivo de bellas páginas a principios del siglo xx en las plumas de Antonio García Cubas (1904, pp. 305-307) y José María Marroquí (1903, pp. 450-453), el primero interesado en la fiesta misma y el segundo más bien como parte de la historia de la capilla de San Eligio de la catedral de México. En fechas más recientes ha sido analizada por diversos autores como parte de las paradojas de la transición a la modernidad en lo religioso y en lo político. Aunque hay matices importantes según las prioridades de cada autor, la fiesta parece servir más como testimonio de continuidades y resistencias que de rupturas. Refiriéndose a los primeros años del siglo XIX, en las postrimerías de la época de las reformas borbónicas, Turrent (2013) escribía: "se impuso una fiesta popular en la catedral de México, en medio de un gobierno ilustrado” (p. 267). Verónica Zárate, una de las pocas autoras que ha llevado el análisis al periodo posterior a la independencia (2005), había ya enfatizado que, para la época de la canonización, si bien "una conmemoración civil desplazó en su carácter nacional a una fiesta religiosa", lo había hecho "sin haber apenas modificado sus características y componentes, solamente el objeto de culto" (Zárate, 2002, p. 361). Ya antes la misma autora había presentado al protomártir como "un mediador cultural" que

${ }^{2}$ Expediente particular promovido por el arzobispo de México. 1777-1779. Sección Audiencia de México. Leg. 2627. Archivo General de Indias (en adelante AGI), Sevilla, España.

${ }_{3}^{3}$ Acta de Cabildo. 16 de febrero de 1797. Sección Actas de Cabildo. Libro 59, f. 78. Archivo del Cabildo Catedral Metropolitano de México (en adelante Ассмм), México.

\section{()ㅜ(1) $\$$}


"contribuyó, mediante su culto, a la formación de la conciencia criolla entre los novohispanos" (Zárate, 2002, p. 357).

En estos estudios hay ciertos incidentes que se han vuelto de obligada mención: en primer término el papel renovador que tuvo Ladrón de Guevara, pero también, y sobre todo, las críticas sobre la fiesta y procesión que, en al menos tres cartas fechadas entre 1802 y 1804, remitió a la Corte de Madrid un anónimo bajo el seudónimo de Francisco Sosa, generando una investigación que puso límites a los proyectos del canónigo (Marroquí, 1903, pp. 451453; Turrent, 2013, pp. 264-267; Zárate, 2002 y 2005). Sobre estos personajes, las opiniones han variado ampliamente. Sobre Guevara, ya Marroquí (1903) advertía que era testimonio de que "la piedad misma es peligrosa en personas no prudentes" (p. 450); hoy en día ya no se le juzga de manera tan severa, pero se ha convertido en testimonio de la oposición a la piedad ilustrada entre las elites novohispanas (Voekel, 2002, p. 65). Sosa (quien también firmaba con el seudónimo de Antonio Gómez), ha recibido una atención particular, por ejemplo de la profesora Zárate (2000), quien lo ha definido como un "proyectista", pero que era parte del "mundo ilustrado" (p. 250). Menos atención ha habido, salvo por esta última autora (Zárate, 2002 y 2005), al hecho de que la fiesta del 5 de febrero alcanzara el título de "fiesta religiosa nacional" por decreto de la legislatura federal en $1826 .{ }^{4}$

Desde nuestro punto de vista es interesante volver sobre este periodo pues nos ilustra algunos de los cambios que desde finales del antiguo régimen y a lo largo de las primeras décadas del siglo xix tienen lugar en materia festiva en Nueva España, en el marco del proceso de secularización en el mundo hispánico. Los estudios sobre este proceso han conocido una renovación importante a escala internacional en los últimos años. Trabajos como los de Roberto Di Stefano (2004) y Sol Serrano (2008) han mostrado la diversidad de aspectos de la vida social que resultaban afectados a consecuencia de los avances de la progresiva separación de las esferas religiosa y política, que constituye el elemento central de ese proceso. En México, si bien no tuvieron lugar los amplios proyectos festivos elaborados en otras latitudes para reemplazar las fiestas cristianas y que han resaltado internacionalmente obras ya clásicas en estos temas (Ozouf, 1976), es cierto que las categorías en que se les ha clasificado (por ejemplo: "regia, revolucionaria y cesariana", Corbin, 1994) bien pueden aplicarse aquí también. Desde luego, ya existen estudios sobre

${ }^{4}$ Hasta donde sabemos, fuera de la capital, sólo en Zacatecas se discutió la inclusión de la fiesta del 5 de febrero como "día de guardia política nacional" (Terán, 2006, p. 269).

\section{()(1) $(3$}


la problemática de la fiesta en la construcción de la nueva nación, como los de Annick Lempérière (2003, pp. 330-346) y, refiriéndose en particular a la oratoria cívico-religiosa, Brian Connaughton (2010, pp. 99-149).

Sin embargo, en general la perspectiva ha sido la del propio Estado nacional, la del ámbito de lo político tratando de construir sus festividades. Aquí, en cambio, tenemos la oportunidad de retomar el tema desde la propia organización festiva corporativa de finales del antiguo régimen, y más específicamente la de uno de los principales cuerpos de la capital del reino de Nueva España, el Cabildo Catedral Metropolitano. Casi resulta obvio decirlo, mas conviene aclararlo, el proceso de secularización no sólo implicó que, con la formación de la esfera política se construyeran nuevas celebraciones, sino también nuevas maneras de evaluar los usos, las prácticas y la organización de las festividades religiosas, las cuales, como lo religioso en general, se fueron convirtiendo en asunto de críticas, de discusión y de opinión pública (Boutry, 1986). Esto es justo lo que nos interesa aquí y el motivo por el que creemos importante volver una vez más sobre la celebración del 5 de febrero.

Vamos a organizar nuestro análisis en tres puntos: en primer lugar, la cuestión de los recursos para la causa de canonización. Aparte de lo que Marroquí (1903) y Turrent (2013), citándolo, han presentado al respecto, en realidad buena parte de la discusión nos permite volver con cierta amplitud sobre el tema de la forma legítima de recabar limosnas, que desde el siglo xVIII se convirtió en uno de los elementos de la crítica ilustrada de las prácticas religiosas. En segundo lugar, respecto de la fiesta propiamente dicha, tenemos que tratar de los dos intentos sucesivos de apropiársela fuera del ámbito estrictamente religioso y eclesiástico. El primero fue obra de la familia Ladrón de Guevara, acusada de imponer "respetos humanos" para su organización, por lo que el medio racionero debió justificar su labor y las novedades que había introducido. El segundo data de unas décadas más tarde, cuando la del protomártir se convirtió en fiesta nacional, planteando, además del problema de las cortesías con las autoridades civiles, la redefinición del propio Felipe de Jesús ahora como protomártir asimismo "nacional". En fin, está el tema de los mensajes religiosos que la fiesta quería transmitir, y en los que vemos incluso el aprovechamiento de un estereotipo de género masculino para fines morales. Más allá de constatar la vigencia de las prácticas barrocas, la celebración del 5 de febrero nos permite abordar la complejidad de lo que conocemos como el catolicismo ilustrado y las controversias que la progresiva autonomía de lo profano producía ya en esos primeros años del siglo XIX.

\section{()(1) $\$$}




\section{DE LA COLECTACIÓN A LA LIBRE VOLUNTAD}

La primera queja de Sosa sobre la fiesta del protomártir había sido por la colectación organizada por el medio racionero Ladrón de Guevara. En su primera carta de $1802^{5}$ comenzaba enumerando los "gravámenes" que este había impuesto "en perjuicio del público". Cierto que la procesión misma, con sus pasos, era ya una de esas cargas, pero venían en seguida las contribuciones en dinero. Primero las de los gremios (Zárate, 2002, pp. 364-370), a quienes "cuestaba", como se decía entonces, pidiéndoles una limosna que "aunque parece voluntaria no lo es en realidad". En segundo lugar, realizaba una colecta más general cada semana, para lo cual "ha formado un padrón de todas las casas". En la segunda carta repitió su protesta por la contribución para los pasos; no se extendía mayormente en ello, pero al final pedía explícitamente que se retirara a Ladrón de Guevara la comisión de la "colectación, rifa o lotería".

Conviene recordarlo, en principio nuestro prebendado era el comisionado para la canonización de Felipe de Jesús por el Cabildo catedralicio. Su primera iniciativa había sido, efectivamente, colectar limosnas, con la particularidad de que serían los propios canónigos, durante la Semana Santa de 1797, quienes "en traje canonical" se ocuparían de ello en la catedral. En las otras iglesias de la ciudad, el medio racionero tenía proyectado invitar para la misma labor a "caballeros cruzados, señores regidores, doctores, abogados". La iniciativa tuvo éxito, y al menos durante nueve años consecutivos "la nobleza y cuerpos de la capital" realizaron una recaudación más bien modesta de poco menos de 200 pesos en promedio. ${ }^{8}$

Más efectiva fue, en realidad, la propia cooperación de los notables capitalinos, segundo medio de colectación introducido de inmediato en marzo de 1797. "Particulares y cuerpos" fueron requeridos constantemente por el prebendado, aportando más o menos un promedio de 1961 pesos anuales. En tercer lugar estuvo la colecta a través de un demandante bajo sueldo (que se descontaba de las propias limosnas), y que rendía menos de la mitad de la ci-

${ }^{5}$ Carta de Francisco Sosa a Ramón de Posada. 26 de febrero de 1802. Sección Audiencia de México. Leg. 2693. AGI, Sevilla, España. Todas las citas que siguen corresponden a este documento hasta nueva llamada.

${ }^{6}$ Carta de Francisco Sosa al rey. 26 de febrero de 1804. Sección Audiencia de México. Leg. 2693. AGI, Sevilla, España.

${ }^{7}$ Acta de Cabildo. 6 de abril de 1797. Sección Actas de Cabildo. Libro 59, f. 90. Aссмм, México.

${ }^{8}$ Acta de Cabildo. 20 de septiembre de 1805. Sección Actas de Cabildo. Libro 62, f. 145. Ассмм, México.

\section{()(1) $\$$}


fra anterior, siempre en promedio, unos 945 pesos anuales, que posiblemente incluían un cepo puesto en la iglesia de San José del Real. Esta era en realidad la colecta pública propiamente dicha, y aunque no lo sabemos con precisión, acaso era para este fin que se había levantado el padrón que mencionó Sosa. La demanda de limosnas, cabe destacarlo, también implicaba gastos. Aparte del pago del colector, fueron necesarias imágenes para salir a la demanda, cuatro alcancías -lo que hace pensar que posiblemente había más de un colector-, además de medallas, estampas, rosarios, novenas y libritos seguramente con la vida del bienaventurado.'

La lista de fuentes de recursos no termina aquí, pues Ladrón de Guevara se distinguía por su laboriosidad. En principio, desde junio de 1797 comenzó a recuperar también las limosnas que los fieles dejaban en sus testamentos bajo lo que se conocía como las "mandas piadosas voluntarias", y que pueden estimarse en poco menos de 340 pesos anuales promedio. Más productivos fueron los "beneficios cómicos", es decir funciones teatrales dedicadas a la causa, uno por año a partir de 1800 , que se puede estimar que resultaban en 491 pesos anuales. ${ }^{10}$

Todo ello nos recuerda ya, aunque la historiografía reciente también lo ha señalado, hasta qué punto la práctica de la limosna era diversificada en el antiguo régimen, e involucraba a todos los grupos sociales (Lempérière, 2004, p. 42). Ser recaudador de la causa del protomártir de la capital era un empleo tan honorable que podían ejercerlo los notables capitalinos, así como en las cofradías peninsulares, las de Sevilla en concreto, no era raro que los propios oficiales salieran a cuestar por las calles (Carbajal, 2016, pp. 339-340). La figura del cuestor de limosnas, religioso como secular, era común en los caminos del reino, equipados como el de Felipe de Jesús con sus imágenes peregrinas y quincallería religiosa abundante (Moro, 2012). Tampoco era novedad que las diversiones públicas financiaran, por ejemplo, la caridad. Tan era legítimo que una de las grandes innovaciones de la atención hospitalaria de la ciudad de México en la segunda mitad del siglo xviıI, el Hospital General, debía obtener recursos de un juego de pelota, con autorización de los propios reformadores capitalinos (Marroquí, 1903, p. 182). Por citar de nuevo un ejemplo trasatlántico, en Sevilla los reñideros de gallos, lugares de apues-

9 Acta de Cabildo. 20 de septiembre de 1805. Sección Actas de Cabildo. Libro 62, fs. 145v-146. АссмM, México.

${ }^{10}$ Acta de Cabildo. 20 de septiembre de 1805. Sección Actas de Cabildo. Libro 62, f. 145. АсCM, México.

\section{()(1) $(3$}


tas, eran propiedad de hermandades que usaban sus ingresos para el culto de sus veneradas imágenes (Carbajal, 2016, p. 287).

Mas es cierto que la recaudación de limosnas comenzaba a causar controversias. La protesta de Sosa se inscribía en las inquietudes reformistas que se habían planteado en Nueva España desde una década antes. En tiempos del virrey Revillagigedo hubo una reforma de las cuestas de limosnas que llevó a su control tanto por la autoridad civil como por la eclesiástica, y que incluso se mezcló con el intento de reforma de cofradías de todo el reino (Moro, 2012, pp. 118-123). Los esfuerzos reformistas de los fiscales que participaron en este último proceso nos muestran bien que Sosa compartía preocupaciones con ellos en este tema. Se esperaba que la limosna fuera, ante todo, moderada y voluntaria, es decir, que no desviara recursos necesarios para la subsistencia de los fieles, y que estos no fueran presionados para entregarla (Carbajal, 2016, pp. 149-154), lo que hace comprensible que nuestro crítico insistiera en que los Ladrón de Guevara interponían "respetos humanos", es decir, la presión social, para obtener estos recursos. Además, la colecta no debía tampoco alterar los espacios y ritos sagrados. La demanda no debía invadir las iglesias ni interrumpir las celebraciones en ellos. Por ello, los reformadores, sin llegar a tomar medidas radicales $-\mathrm{y}$ sin cuestionar aún otras contribuciones religiosas como el diezmo o las obvenciones-, promovieron más bien que se limitara a cepos, alcancías o bien mesas en el umbral de la puerta de las iglesias (Carbajal, 2016, pp. 152-154).

El prebendado Ladrón de Guevara parece consciente de estos cambios, al menos hasta cierto punto. Además de haber obtenido licencia episcopal y virreinal, ya hemos visto que la colecta de Semana Santa en las iglesias correspondía bien a lo esperado por los reformadores. Lo paradójico es que se diría que tampoco sus colegas canónigos miraban con absoluta complacencia el fondo que el medio racionero iba reuniendo, sino antes bien con precauciones. Cuando las limosnas comenzaron a acumularse, fueron depositadas provisionalmente en la clavería de la catedral. Al menos desde mayo de 1800, cuando de manera incidental hacen alusión a ellas en un Cabildo, los canónigos comenzaron a tratar de tomar medidas. Para el mes de noviembre del mismo año, la caja de clavería estaba llena, por lo que las limosnas se pasaron al "arca general de depósitos". Lamentablemente no sabemos cuál fue el importe preciso que se trasladó entonces. ${ }^{11}$

${ }^{11}$ Acta de Cabildo. 7 y 11 de noviembre de 1800. Sección Actas de Cabildo. Libro 60, fs. 79v-81. Ассмм, México.

\section{()(1) $(9$}


Como ya lo hizo notar Turrent (2013, p. 265), el prebendado tuvo problemas con el Cabildo catedralicio por haber pretendido que su comisión para la canonización del protomártir le permitiera ganar horas del coro. Ante la negativa del Cabildo, recurrió a la Real Audiencia de México por la vía del recurso de fuerza. En medio de esas peripecias judiciales, en 1802 el Cabildo catedralicio consideró incluso su reemplazo, citando siempre la necesidad de custodiar el fondo reunido para la canonización, bien que sin llamar a cuentas al siempre inquieto medio racionero. ${ }^{12} \mathrm{Al}$ final logró mantener su comisión, pero una serie de coincidencias jugaron en su contra: la segunda carta de Sosa pudo no haber insistido tanto en el tema de la colecta, pero fue vista en el Consejo de Indias por Lorenzo Hernández de Alva, fiscal que había sido de la Audiencia al tiempo de su problema con el Cabildo catedralicio, y uno de los reformadores en materia tanto de limosnas como de cofradías. En su dictamen del 6 de noviembre de 1804 recomendó no sólo que se pidieran informes en general, como había ocurrido con la carta de 1802, sino que se atendiera en particular el asunto de la colecta, y en efecto el Consejo mandó que esta cesara de inmediato si no contaba con licencia real. ${ }^{13}$

Fue así como en 1805 el canónigo debió presentar cuentas detalladas, que ya hemos examinado en parte. Ahora hay que agregar que justo al mismo tiempo que Sosa firmaba su carta, en enero de 1804 el prebendado había comenzado a percibir ingresos de una última fuente, gestionada desde el año anterior: una rifa, semanal sin duda, realizada a través de la Real Lotería. ${ }^{14}$ Este fue, por mucho, el ingreso más significativo de la obra de canonización pues sólo en 88 semanas ya había producido 10249 pesos. Tan sólo este ingreso compensaba por completo los gastos realizados desde 1797, que el prebendado estimó en unos 9055 pesos y que contrastan con los 45646 de ingresos totales, 36450 de los cuales llegaron a estar depositados en la catedral. Además de lo que ya dijimos que era necesario para la cuesta de limosnas, atendió también el culto en la capilla de la catedral, y por supuesto, hubo que cubrir diversas gestiones y cartas. ${ }^{15}$

${ }^{12}$ Acta de Cabildo. 3 de julio de 1802. Sección Actas de Cabildo. Libro 60, f. 263v. AccMM, México.

${ }^{13}$ Dictamen del fiscal del Consejo de Indias. 6 de noviembre de 1804. Sección Audiencia de México. Leg. 2693. AgI, Sevilla, España.

${ }^{14}$ Acta de Cabildo. 20 de septiembre de 1805. Sección Actas de Cabildo. Libro 62, f. 145. Ассмм, México.

15 Acta de Cabildo. 20 de septiembre de 1805. Sección Actas de Cabildo. Libro 62, fs. 145v-146. Ассмм, México.

\section{()(1) $(9$}


En suma, pues, los esfuerzos del prebendado entre marzo de $1797 \mathrm{y}$ enero de 1804 habían permitido recaudar 35397 pesos de limosnas. No era una cifra menor, constituía sin duda un triunfo para el prebendado, el testimonio de que su campaña a favor del protomártir tenía éxito, aunque también lo era del relativo apoyo del vecindario de la capital: si la midiéramos por las limosnas aportadas, se diría que la de Felipe de Jesús era devoción de los notables. Ahora bien, la denuncia de Sosa resultó en que ahora la colecta tenía que adecuarse ya no sólo de forma parcial, sino integralmente a las exigencias de los reformadores en la materia. Ya en octubre de 1805, el fiscal de lo civil dictaminaba que la limosna podía subsistir, pero no la cuestación: debía recibir exclusivamente lo "que los devotos quieran espontáneamente dar". Por ello las mandas testamentarias, siendo explícitamente "piadosas voluntarias", podían continuar al igual que el "beneficio cómico", desde luego "si los actores lo quisieren continuar espontáneamente"; podían también subsistir el cepo de San José del Real y una bandeja en la catedral, pero siempre "sin asistencia de ninguna persona" ${ }^{16}$

Parecía que a consecuencia de la carta de Sosa la libre voluntad como criterio fundamental de legitimidad de las contribuciones religiosas venía a imponerse en la obra de canonización; empero, el dictamen final de marzo de 1806 de Ambrosio de Sagarzurrieta declaró que "no ha habido gravamen público" con la colecta y que "en todo ha obrado la voluntaria devoción", aclarando explícitamente que ni "a gremios ni a persona alguna se le haya exigido por fuerza o por medios violentos directa o indirectamente la limosna". ${ }^{17}$ Mas la decisión final quedó en manos del Consejo de Indias, donde en 1807 el fiscal y el tribunal coincidieron no sólo en insistir en el carácter voluntario, sino además en introducir un criterio de racionalidad: el prebendado debía probar la "legítima inversión" que había de darse a lo recaudado, "y que se necesita[ba] mayor suma" para que se le permitiera continuar reuniendo fondos. ${ }^{18}$ Un nuevo reclamo de Ladrón de Guevara en 1810 tuvo, en cuanto a lo primero, prácticamente la misma respuesta del Consejo y Tribunal Supremo

${ }^{16}$ Dictamen del fiscal de lo civil. 9 de octubre de 1805. Testimonio de expediente instruido a consecuencia de la real cédula de S. M. sobre colectación de limosnas para la canonización del beato Felipe de Jesús. Sección Audiencia de México. Leg. 2693. AGI, Sevilla, España.

${ }^{17}$ Dictamen del fiscal de lo civil. 31 de marzo de 1806. Testimonio de expediente instruido a consecuencia de la real cédula de S. M. sobre colectación de limosnas para la canonización del beato Felipe de Jesús. Sección Audiencia de México. Leg. 2693. AGI, Sevilla, España.

${ }_{18}$ Dictamen del fiscal y resolución del Consejo de Indias. 7 y 12 de febrero de 1807. Sección Audiencia de México. Legajo 2693. AGI, Sevilla, España.

\section{()ㅜ(1) 3}


de España e Indias: "la cuestación sea absolutamente voluntaria por medio de cepos", pero dejó a cargo del Cabildo catedralicio el tomarle cuentas al medio racionero. ${ }^{19}$

Aunque no tenemos plena constancia de que el Cabildo haya recibido la real cédula que debió librarse en septiembre de 1811, es cierto que ya a fines de 1814 comenzaba a ocuparse de volver a tomarle cuentas a Ladrón de Guevara. ${ }^{20}$ Mas fue sólo hasta diciembre de 1816 que este presentó un nuevo informe completo, particularmente desolador cabe decir. La colecta de limosnas se encontraba en el estado "más deplorable", afirmaba, pues en realidad, de las diversas formas de colecta sólo había quedado el plato de la catedral; subsistían las mandas piadosas pero sólo las estimaba en 25 pesos mensuales, y la rifa había generado sólo 70 pesos entre 1811 y $1816 .{ }^{21}$

Desconfiados, los canónigos procedieron a verificar los dichos de Ladrón de Guevara. Ya en enero de 1817 el maestrescuelas presentó a los canónigos una razón más detallada, elaborada en la Real Lotería, que sin embargo confirmó la disminución también de esos ingresos: entre 1805 y 1809 se habían recaudado poco más de 5684 pesos, es decir, en cuatro años apenas poco más de la mitad de lo que había producido en su primer año y nueve meses; hubo más de 2000 pesos de pérdidas entre 1810 y 1812 y en los años de 1813 a 1815 apenas habían ingresado unos 218 pesos. ${ }^{22}$ Todavía era una suma respetable la que se había depositado en la clavería, pues ascendía a casi 37740 pesos, pero claramente apenas había habido un incremento de 2343 pesos aproximadamente. El punto final definitivo de la colecta fue la sustitución, ya en 1820 , del demandante que todavía tenía encargado el plato de la catedral, directamente por un cepo. ${ }^{23}$

Debió pasar más de una década para que el asunto se volviera a tratar en la sala de cabildos de la catedral. Y el motivo no pudo ser más significativo: en septiembre de 1833 falleció don Joaquín José Ladrón de Guevara, entonces ya deán de la catedral metropolitana. Enterrado en secreto en el Cole-

19 Dictamen del Consejo. 17 de mayo de 1811. Sección Audiencia de México. Leg. 2698. AGI, Sevilla, España.

${ }^{20}$ Acta de Cabildo. 20 de diciembre de 1814. Sección Actas de Cabildo. Libro 67, f. 262v. Ассмм, México.

${ }^{21}$ Acta de Cabildo. 4 de diciembre de 1816. Sección Actas de Cabildo. Libro 68, fs. 185185v. АсСмм, México.

${ }^{22}$ Acta de Cabildo. 10 de enero de 1817. Sección Actas de Cabildo. Libro 68, fs. 197v-198. Ассмм, México.

${ }^{23}$ Acta de Cabildo. 29 de febrero de 1820. Sección Actas de Cabildo. Libro 69, f. 195v. Ассмм, México.

\section{()(1) $\$$}


gio Apostólico de San Fernando de México, el 22 de octubre los canónigos se ocuparon de revisar el inventario de la causa de canonización presentado por su albacea. Entonces se estimaron depositados en clavería un total de 37672 pesos, es decir, había una diferencia de 68 pesos menos respecto de 1817 , y se nombró una comisión de dos canónigos para la revisión de cuentas. ${ }^{24}$

Los vaivenes políticos de la primera reforma liberal impidieron que los comisionados pudieran actuar de inmediato, pero uno de ellos pudo al menos informar en enero de 1834 las dificultades para reactivar la obra. En principio, tomarle cuentas al difunto deán era complicado, pues su albacea habría dicho que "estaban tan enredados los papeles y tan dispersos que ni en dos ni tres años se podrían poner acordes". ${ }^{25}$ Lo que sí pudo adelantarse fue la apertura del cepo de la catedral, aunque debió romperse a falta de llave, y se abrieron también diversas alcancías (tal vez alguna era la que había estado en San José del Real), reuniéndose así 115 pesos. Nada se sabía del tema de las mandas testamentarias, ni se mencionó aun el de la rifa en la Lotería, en cambio, el comisionado pudo recibir las imágenes, "medallas, estampas, vidas, novenas y días" de Felipe de Jesús, es decir, todo lo que había quedado de la entusiasta empresa de recolección iniciada en 1797.

Claramente la carta de Sosa había sido decisiva para su interrupción, y continuarla bajo los nuevos criterios y en el contexto de la independencia había sido al menos complicado. Sin el trabajo de promoción, los habitantes de la capital no contribuían espontáneamente para la causa de canonización, por lo cual esta, ya lo ha señalado Zárate (2002) "permaneció en un estado inanimado" (p. 361). No sabemos cuál sería el destino final de lo que se había acumulado en la clavería de la catedral, pero en cambio podemos confirmar una primera alteración, producto de esa idea entonces novedosa y propia ya del proceso de secularización, de que las contribuciones para las prácticas, causas e instituciones religiosas se distinguían de las que recaudaban las instituciones políticas en que no podían ser obtenidas por coacción sino por libre voluntad. Es momento de dar una nueva vuelta por esta historia, pero volviendo ahora la mirada a la fiesta y sus definiciones.

${ }^{24}$ Acta de Cabildo. 13 de septiembre y 22 de octubre de 1833. Sección Actas de Cabildo. Libro 73, fs. 102v-103 y 110. АссмM, México.

${ }^{25}$ Acta de Cabildo. 22 de enero de 1834. Sección Actas de Cabildo. Libro 73, fs. $142 v-143$. Ассмм, México. Los datos que siguen corresponden también a esta referencia.

\section{()(1) $\$$}




\section{DE ACOMPAÑAMIENTO POLÍTICO A FIESTA NACIONAL}

Es momento ya de señalar las novedades propiamente festivas introducidas por Ladrón de Guevara en el festejo del protomártir en la catedral. Para la época que nos ocupa se mantenía vigente el traslado de la imagen del convento franciscano -el día 4 de febrero-al promediar las dos de la tarde. Esta procesión era la que reunía la mayor solemnidad: franciscanos y dieguinos portaban la efigie, precedida por el gremio de plateros con hachas de cera en mano en medio de "colgaduras y fuegos, repiques, arcos de tule y demás acciones de aplauso". ${ }^{26}$ El Cabildo catedralicio salía a recibirlos a la puerta del costado poniente, pero "sin clero, cruz y ciriales". Al día siguiente había procesión conforme al rito de primera clase que era propio de la fiesta, pero era circum circa, es decir, por el atrio y con estación a la capilla del beato, realizándose, como todas las de este tipo, al final del oficio de tercia y antes de la misa. Los franciscanos volvían a su convento en comunidad al terminar la misa y el oficio de sexta, y llevándose la estatua del beato. ${ }^{27}$ La Gazeta de México lo anotaba ya en 1801, incluso, 1799, se decía que "la segunda procesión [tercera en realidad] era en todo igual a la primera". ${ }^{28}$

En estudios anteriores (Marroquí, 1903, p. 450; Turrent, 2013, p. 265) ya se ha mencionado que una de las primeras ideas del medio racionero Ladrón de Guevara para dar mayor publicidad al beato fue reforzar la fiesta a través de uno de los medios clásicos de la época: reunir a más corporaciones (Lempérière, 2004, pp. 209-210). Trató de completar la fiesta con un novenario con asistencia de las comunidades religiosas de la capital, pero no obtuvo la aprobación del arzobispo. El 1 de febrero de 1799 presentó al Cabildo un intento para modificar la procesión del día 5, realizándola "por lo bajo de la banqueta del cementerio", es decir, por fuera de este. Se entiende en consecuencia que estaba tratando de alterar la procesión de tercia, prolongándola para su mayor lucimiento, y porque a ella asistirían seis corporaciones, pero

${ }^{26}$ Manuscrito. Diario manual de lo que en la catedral de México se practica y observa en su altar, coro y demás... 1751. Fondo Antiguo. Ms. 12066, fs. 64-64v. Biblioteca Nacional de España, Madrid (en adelante BNE), Madrid.

${ }^{27}$ Manuscrito. Instrucción del orden y método con que se celebran los divinos oficios en la Santa Iglesia Catedral Metropolitana de México... 1794. Fondo Antiguo. Ms. 12506, f. 44v. BNE, Madrid.

${ }^{28}$ Gazeta de México, 1 de marzo de 1801, t. x, núm. 32, p. 253.

\section{()(1) $(9$}


el Cabildo se negó a conceder este cambio. ${ }^{29}$ Tras este segundo desaire, no es de extrañar que, en 1800, el canónigo terminara aprovechando la tercera procesión para introducir, no sólo a las nuevas corporaciones, sino el desfile de representaciones de la vida del santo. Se agregaron finalmente las parcialidades de indios, los gremios, las terceras órdenes de servitas y franciscanos, los colegios de San Ildefonso, Seminario o San Juan de Letrán, la Universidad y el Ayuntamiento. ${ }^{30}$ Al examinar la carta de Sosa en 1804, don Lorenzo Hernández de Alva recordó que el activo medio racionero intentó también que asistiera la Real Audiencia, sin éxito. ${ }^{31}$ Así, cabe destacarlo, a falta de magistrados reales, y canónigos, y aunque seguía siendo en principio del público, también se había vuelto una fiesta de la propia familia Ladrón de Guevara. Tal hecho había sido un punto destacado por Sosa, la procesión pudo reorganizarse gracias a los "respetos humanos", es decir, al prestigio y autoridad del prebendado y sobre todo de su padre, Baltasar Ladrón de Guevara, regente de la Real Audiencia. Cuando llegaran a desaparecer uno y otro, escribió Sosa, "ni quien se acuerde de la función de San Felipe de Jesús". ${ }^{2}$

Ahora bien, al momento de responder en el expediente formado a consecuencia de las cartas de Sosa, es significativo, y lo notó el fiscal Sagarzurrieta en dictamen de 17 de febrero de 1804, que Ladrón de Guevara y el Ayuntamiento de México prefirieron utilizar el término "acompañamiento" en lugar de procesión para referirse a ese renovado tercer y más grande cortejo con la imagen. ${ }^{33}$ Se diría que, así como con las limosnas, Sosa había atinado a tocar un punto particularmente sensible, pues obligaba al medio racionero a explicar las innovaciones que no se le habían permitido en las otras procesiones.

\footnotetext{
${ }^{29}$ Acta de Cabildo. 1 de febrero de 1799. Sección Actas de Cabildo. Libro 59, f. 271. AccMM, México.

${ }^{30}$ La relación del orden de la procesión hecha por Ladrón de Guevara en 1804, en carta de Ladrón de Guevara al virrey. 10 de marzo de 1804. Testimonio de expediente instruido a consecuencia de la real cédula de S. M. sobre colectación de limosnas para la canonización del beato Felipe de Jesús. Sección Audiencia de México. Leg. 2693. AgI, Sevilla, España. El Diario de México publicó una relación asimismo detallada en 1806, que presenta como variante la inclusión de la comunidad de San Cosme y la ausencia de los servitas: Diario de México. 8 de febrero de 1806, t. 2, núm. 131, p. 156 analizada por Zárate (2002, pp. 368-369).

${ }^{31}$ Dictamen del fiscal del Consejo de Indias. 6 de noviembre de 1804. Sección Audiencia de México. Leg. 2693. AgI, Sevilla, España.

${ }^{32}$ Carta de Francisco Sosa al rey. 26 de febrero de 1804. Sección Audiencia de México. Leg. 2693. AGI, Sevilla, España.

33 Dictamen del fiscal de lo civil. 17 de febrero de 1804. Testimonio de expediente instruido a consecuencia de la real cédula de S. M. sobre colectación de limosnas para la canonización del beato Felipe de Jesús. Sección Audiencia de México. Leg. 2693. AgI, Sevilla, España.
}

\section{(ㄷ)(1) $(3$}


En contestación a lo planteado por el fiscal, el propio medio racionero debió confesar: "No es ésta ni puede llamarse procesión eclesiástica porque para que alguna lo sea debe preceder licencia del ordinario." ${ }^{34}$ Evidentemente no la había solicitado, y es muy probable que el arzobispo Lizana no la hubiera concedido, si nos atenemos a lo sucedido con la novena, pero de todas formas aclaraba: "aquí no se necesita, porque todo está reducido a acompañar a la antigua imagen del santo que necesariamente se había volver a su casa o templo". Completaba su explicación aduciendo además que no era procesión porque no iban cruz alta ni ciriales, ni la presidía preste con capa pluvial, sino sólo iban en ella "cuerpos exentos [como las órdenes religiosas], políticos y personas distinguidas", lo que era tanto como decir que no era procesión eclesiástica porque no iba en ella el clero secular.

Curiosa paradoja, el organizador de un cortejo tan barroco, de aires tan tradicionales, y que desde luego confesaba que su utilidad no era otra que la propaganda de la devoción, no encontraba otra manera de definirlo que aceptar que estaba desacralizándolo en cierta medida. La única vía que encontró para justificar su apropiación había sido sacar a la procesión, al menos de forma retórica, del ámbito religioso. El arzobispo Lizana no pudo sino corregir con energía en el informe antes mencionado: "semejante acompañamiento a las sagradas imágenes, sean los que fueren los católicos que las acompañan, es por sí mismo un acto exterior de adoración no política sino sagrada" ${ }^{35}$ Ladrón de Guevara era sospechoso de error y hasta de herejía, tanto más cuanto que incluso había construido su "acompañamiento político" contrastándolo con una "procesión eclesiástica”. El prelado no pudo sino preguntarse "cuál es el constitutivo de la [procesión] no eclesiástica". De alguna forma la definición de "acompañamiento" del medio racionero -repetida ante el Consejo de Regencia en $1810-{ }^{36}$ confirmaba la acusación fundamental de Sosa, a su vez señalada por el arzobispo: se trataba de una práctica en que lo sagrado se mezclaba con algo profano.

${ }^{34}$ Carta de Ladrón de Guevara al virrey. 10 de marzo de 1804. Testimonio de expediente instruido a consecuencia de la real cédula de S. M. sobre colectación de limosnas para la canonización del beato Felipe de Jesús. Sección Audiencia de México. Leg. 2693. AGI, Sevilla, España. Las siguientes citas corresponden a esta misma carta hasta nueva llamada.

${ }^{35}$ Informe del arzobispo de México. 6 de marzo de 1806. Testimonio de expediente instruido a consecuencia de la real cédula de S. M. sobre colectación de limosnas para la canonización del beato Felipe de Jesús. Sección Audiencia de México. Leg. 2693. AGI, Sevilla, España.

${ }^{36}$ Carta de Ladrón de Guevara al Consejo de Regencia. 19 de septiembre de 1810. Sección Audiencia de México. Leg. 2698. AGI, Sevilla, España.

\section{()ㅜ(1) 3}


Unos años después de la carta de Sosa, con la independencia en 1821, el festejo que tanto había costado organizar a Ladrón de Guevara cobró además renovado interés político, ya no sólo para una familia poderosa de la capital, sino para las autoridades de la nueva nación, toda vez que "la religión católica seguía cumpliendo su papel tradicional de lazo político" (Lempérière, 2003, p. 331). Los estudios recientes han profundizado en la importancia que mantuvo la fiesta religiosa y la difícil construcción de las festividades cívicas (Connaughton, 2010; Zárate, 2004). En este contexto, el brillante "acompañamiento" del protomártir no pasó desapercibido: hubo un intento de apropiación desde las nacientes instituciones nacionales.

En efecto, lo recordaría el Cabildo catedralicio más tarde, la fiesta del 5 de febrero de 1823 tuvo una característica particular: por primera vez asistió una autoridad superior al Ayuntamiento, el entonces emperador Agustín I. ${ }^{37}$ Felipe de Jesús pasaba de ser el protomártir de la ciudad de México al de la nueva nación, que aunque estaba organizada bajo principios seculares, estando fundada con el compromiso de defender la religión católica, no podía sino celebrarlo de manera particular. En ese sentido argumentaba José Joaquín Fernández de Lizardi, publicista célebre de la época. Además de haber publicado un cántico para el beato en 1811, en 1821 había "revivido" la voz de la madre del protomártir para solicitar al Ayuntamiento de México que lo celebrara como integrante de la nueva nación (Fernández de Lizardi, 1821; 1963, pp. 227-230).

Mas el primer imperio duró poco y no pudo darle continuidad a la celebración. Fue bajo el primer federalismo, en 1824, cuando se comenzó a tratar el establecimiento de las fiestas nacionales. En noviembre de 1824 tocó todavía al Congreso Constituyente expedir un primer decreto en que se incluyeron las "fiestas religiosas nacionales" (Dublán y Lozano, 1876, p. 745) y la primera legislatura federal volvió sobre el tema en 1825. Tan pronto como el 18 de enero de ese año, la Cámara de Diputados dio lectura a un dictamen de su comisión eclesiástica proponiendo la inclusión del 5 de febrero entre las fiestas religiosas nacionales; más todavía se propuso de inmediato darle trámite sin dilación ante la proximidad de la celebración. Sin embargo, el contexto había cambiado y la fiesta no era ya aceptada de manera unánime: para convertirse en nacional, la del protomártir debió superar la crítica de aquellos que favorecían una disminución al menos progresiva de la imbricación entre lo político y lo religioso.

${ }^{37}$ Acta de Cabildo. 6 de febrero de 1826. Sección Actas de Cabildo. Libro 71, f. 150. AccMM, México.

\section{()(1) $(3$}


En la Cámara de Diputados el dictamen se impuso por mayoría de 38 contra diez en la votación nominal con sólo las objeciones del diputado Vélez. ${ }^{38}$ En el Senado, en cambio, la cuestión fue más controvertida. El proyecto se pasó a dictamen de la Comisión de Gobernación, y se puso a discusión del pleno hasta el 8 de febrero, y entonces hubo un intento de devolverlo a la otra Cámara cuestionando la dispensa de trámites. ${ }^{39}$ Esto no prosperó, pero se envió a nuevo dictamen, ahora a la Comisión de Negocios Eclesiásticos, que al igual que la anterior rechazó el proyecto. Fue hasta la sesión del 25 de enero de 1826 que se discutió en el pleno del Senado. ${ }^{40}$ Cuatro legisladores, Juan de Dios Cañedo, Valentín Gómez Farías, el padre José María Alpuche y el canónigo poblano José Manuel Couto arguyeron en contra. Presentaron ampliamente las críticas de los ilustrados y liberales contra la holgazanería y a favor del trabajo, citando como autoridad al padre Feijoo. El Congreso, afirmaron, debía "desterrar la pereza e inspirar el amor al trabajo", en aras de promover al mismo tiempo la "riqueza nacional" y proteger la "moral pública". Argumentación clásica y en realidad hoy bien conocida en la crítica social tanto de los ilustrados como del liberalismo (Callahan, 1989; Hale, 1999), es además interesante que Couto agregara el perjuicio de las asistencias públicas, que propiciaban el "envanecimiento" de los funcionarios.

En respuesta, los senadores Posada, Vea y Cevallos afirmaron que la interrupción de labores era poco probable y como mucho podría afectar a la ciudad de México, que era el único lugar donde realmente se festejaba. Mas sobre todo se impuso el argumento de la condición de México como nación católica, que convirtió al mártir en un connacional: Felipe de Jesús era "el único mexicano que veneramos en los altares y un héroe de la religión”. Y justo en esos términos se publicó el decreto el día 28 de enero de 1826: la fiesta del "mártir mexicano" quedaba incluida en las fiestas enlistadas como religiosas nacionales en noviembre de 1824 (Dublán y Lozano, 1876, p. 770).

En cumplimiento de esta ley, el presidente Guadalupe Victoria y sus ministros asistieron a la función del 5 de febrero de 1826. Ya se había estado construyendo un protocolo para el trato a las autoridades nacionales en la

${ }^{38}$ Cámara de Diputados. Sesión del día 18 de enero de 1825. El Sol, 20 de enero de 1825, año 2, núm. 584, p. 914.

${ }_{39}$ Cámara de Senadores. Sesión del día 8 de febrero de 1825. El Sol, 10 de febrero de 1825, año 2, núm. 607, p. 997.

${ }^{40}$ Cámara de Senadores. Sesión del día 25 de enero de 1826. El Sol, 28 de enero de 1826, año 3, núm. 956, p. 914, y El Águila Mejicana, 29 de enero de 1826, año III, núm. 290, p. 2. Todas las citas que siguen proceden de estas referencias hasta nueva llamada.

\section{()(1) $\$$}


catedral, por lo que esto no hubiera suscitado novedad, de no ser porque el gobierno incluyó además la presencia del presidente en la procesión de Ladrón de Guevara, la que iba de la catedral a San Francisco y que por ello cobró un realce que no había alcanzado durante el tiempo virreinal. Mas los canónigos, además de siempre algo reacios a la novedad en materia de ceremonias, antepusieron la atención del coro, su deber sagrado, faltando a las "consideraciones debidas al presidente de la república". Al menos así se planteó en la Cámara de Senadores federal el día 9 de febrero de 1826 por el padre José María Alpuche. "Según se aseguraba en el público", declaró el senador, el presidente había tenido que esperar a que se concluyera el oficio de tercia para que empezara la misa y luego el de nona para que saliera la procesión, en la que los canónigos, como era costumbre, no participaron. ${ }^{41}$

El gobierno pidió cuentas al Cabildo Catedral Metropolitano a través del Ministerio de Justicia y Negocios Eclesiásticos, a cargo del también canónigo, pero poblano, Miguel Ramos Arizpe. El 17 de marzo, el ministro comunicó a los canónigos que debían invertir sus prioridades y "arreglar el rezo y demás distribuciones de la Iglesia de modo que aquella autoridad suprema de la nación sólo esté en ella mientras dure la función a que asista”. Además se les impuso la obligación de asistir a la procesión a San Francisco así como a cualquier otro "anexo", acompañando al presidente. ${ }^{42}$ Reticentes a desatender el coro, en abril los canónigos prefirieron aceptar la definición de Ladrón de Guevara de principios del siglo y desacralizar dicha práctica: "el Cabildo no ha salido en esta procesión [...] por no ser tal procesión, sino una mera conducción de las imágenes". ${ }^{43}$ Por fin, casi en vísperas de la siguiente celebración, el 1 de febrero de 1827, el gobierno aceptaba la distinción entre procesión "ritual y solemne" y la "traslación", acaso no tan ritual pero "con el decoro y orden correspondiente"; ${ }^{44}$ la primera, como era costumbre, en la mañana y justo antes de la misa, recorriendo el atrio; la segunda, se recorría en la tarde.

Esta resolución, final hasta donde sabemos, permitía a los canónigos proteger lo sagrado y cumplir con lo profano, que ya no eran los "respetos

${ }^{41}$ Cámara de Senadores. Sesión del día 9 de febrero. El Águila Mejicana, 14 de febrero de 1826, año III, núm. 306, p. 1.

${ }^{42}$ Acta de Cabildo. 18 de marzo de 1826. Sección Actas de Cabildo. Libro 71, fs. 158-158v. Ассмм, México.

${ }^{43}$ Acta de Cabildo. 14 de abril de 1826. Sección Actas de Cabildo. Libro 71, fs. 163-163v. Ассмм, México.

${ }^{44}$ Acta de Cabildo. 3 de febrero de 1827. Sección Actas de Cabildo. Libro 71, f. 242. AccMM, México.

\section{()(1) $\$$}


humanos" de la familia Ladrón de Guevara, sino el honor de la nación misma. Desde luego, el cambio no dejó de sorprender a la opinión pública, que se ocupó de criticarlo. Un folletista (Dávila, 1828) planteaba en 1828 que no era sino una forma de "hacerse originales y no parecerse en nada a los españoles", pero que iba en detrimento de la propia función, que ahora contaba con "lucidísimo acompañamiento", no sólo de las autoridades, sino hasta de "todo lo alto y bajo de la capital". Más todavía, el horario iba en perjuicio de su carácter, que el folletista entendía debía imponerse sobre los festejos corporativos tradicionales: "imítense las procesiones de los barrios y de frailes en una función nacional", decía concluyendo con reclamar el uso de la vela del Corpus para la carrera de la traslación (p. 106).

Como podemos ver, en la historia de esta procesión los intentos de realzarla eran otros tantos motivos de controversia. En los primeros años del siglo xix parecía que se había convertido en motivo de honor de los Ladrón de Guevara, en 1826 se convertía en elemento de una fiesta nacional. En uno y otro caso se reforzaba su aspecto político, mas para la década de 1820 había quedado específicamente en medio de las tensiones entre las respuestas "liberal" y "galicana", a la pregunta de "iqué hacer con la religión?" en el nuevo régimen, por parafrasear la terminología utilizada para los estudios en otras latitudes (Di Stefano, 2004); es decir, entre quienes eran más favorables al deslinde de esferas y quienes esperaban establecer el control de lo religioso por lo político, dos de las maneras principales de afrontar el proceso de secularización en esta época. Mas no hemos agotado aún los cambios producto de dicho proceso, nos queda un último señalamiento, el más extenso y sentido que había hecho Sosa: la presencia en la procesión de un "currutaco".

\section{LOS COMBATES DEL SIGLO}

"Ha alterado el orden de la seria disciplina que debe guardarse en las procesiones, las que deben ser para el pueblo un acto de la mayor circunspección y gravedad, no siéndolo ésta procesión por dar materia a risa y jácara." ${ }^{45} \mathrm{Tal}$ era el tercero de una segunda serie de reclamos sobre el tema de la "disciplina de la Iglesia" que Francisco Sosa, en su carta de 26 de febrero de 1802,

${ }^{45}$ Carta de Francisco Sosa a Ramón de Posada. 26 de febrero de 1802. Sección Audiencia de México. Leg. 2693. AGI, Sevilla, España. Las citas siguientes proceden de este mismo documento.

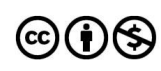


dirigió a Ramón de Posada, fiscal de la sección novohispana del Consejo de Indias. De hecho, se trataba del punto más estrictamente religioso de toda su denuncia en contra del festejo a Felipe de Jesús organizado por el medio racionero Ladrón de Guevara. Ya lo han visto los estudios mencionados antes, y sin duda es cierto: Sosa era testimonio del desagrado con que el catolicismo ilustrado veía el fasto religioso, pero también e incluso antes que ello, la procesión misma lo era del combate que ciertos sectores del catolicismo habían emprendido contra la cultura profana en esos primeros años del siglo XIX, aprovechando estereotipos de género, construidos asimismo bajo principios religiosos.

Veamos esto con detalle. Sosa de inmediato continuaba describiendo: la procesión estaba formada por una serie de pasos en que se representaban "uno por uno los pasajes de la vida del santo", ilustrándolos de manera precisa. Tres de ellos aparecen particularmente descritos: "de comerciante, como en el acto material de ir bendiciendo y vareando los géneros", "de estudiante" y, el más controvertido: "de aprendiz de platero en donde va el diablo o demonio vestido en un traje ridículo tentándolo". En contraste, es cierto, recordaba que la representación de los santos debía ser específicamente religiosa: "o en el martirio que sufrieron o en el género de penitencia que florecieron, para que muevan al público a devoción".

Sosa no argumentó entonces los motivos para haber mencionado esos pasos en concreto, pero no es difícil suponer, por el tono de la redacción, que en el primero estaba el problema de la mezcla de la imagen del protomártir con un oficio completamente profano, como el comercio, y que en el último el problema fundamental era el traje que llevaba el diablo, profano asimismo, pero sobre todo por su carácter ridículo. Sobre ello abundó un poco más en su segunda carta, la fechada el 26 de febrero de 1804, describiéndonos con más claridad al diablo en cuestión, que nuevamente resultaba fundamental en la crítica de nuestro proyectista ilustrado: "vestido de pantalón, media bota, sus bucles, su espada, su casaca y en fin vestido el diablo de un perfecto currutaco". ${ }^{46}$ En julio de 1805 el arzobispo de México, Francisco Xavier Lizana, confirmaba que esa imagen "choca[ba]" y completaba su descripción. Se trataba de "una estatua en figura de diablo con astas y cola, vestida de casaca larga, pantalón y media bota, llamada de cucaracha, a la manera

${ }^{46}$ Carta de Francisco Sosa al rey. 26 de febrero de 1804. Sección Audiencia de México. Leg. 2693. AGI, Sevilla, España.

\section{()(1) $(9$}


del vestido que traen los que dicen ser de última moda y reconoce el vulgo por currutacos". ${ }^{47}$

El "currutaco", conviene explicarlo brevemente, era una representación del género masculino de la época que, en la línea del "petimetre" antes y del "lechugino" más tarde, era un estereotipo del varón preocupado por la moda, especialmente por la francesa. Asociado al pecado de la vanidad, que en las representaciones de género de la época era por definición propio de las mujeres, venía a quedar vinculado al afeminamiento y a las prácticas homosexuales. Se entiende en ese sentido que el guardián del convento de San Diego de México, de franciscanos descalzos, se refiriera a la imagen en su informe al virrey de agosto de 1803 a propósito de la procesión con los términos más severos, justificándola. Era ridícula, ciertamente, pero justo con la intención de "desterrar el abuso indecentísimo con que se cubren los hombres, afrenta de nuestro sexo y del Cristianismo" ${ }^{48}$ En el mismo sentido fue la explicación del guardián del convento de San Francisco de México, de franciscanos observantes, fray José Tamariz. El religioso aclaraba: "el santo no mueve a risa, sino el diablo, digno de burla", e insistía en la diabolización de la vanidad: "el vestir así al diablo es detestación de la profanidad de los trajes diabólicos que en esta época infeliz trajo del infierno ese enemigo". ${ }^{49}$ En 1810, finalmente, el propio Ladrón de Guevara justificó esta representación exactamente con los mismos términos: "el vestido que se le puso fue el mismo contra el que entonces se declaraba vivamente en los púlpitos y aun en varios papeles profanos de prosa y verso, los que me pareció ayudaría para desterrarlo, representar con él a nuestro enemigo común", afirmó.

En suma, pues, sobre todo esta última declaración, es testimonio de que uno de los problemas fundamentales de esta procesión es que salía en ella una imagen explícitamente de combate contra una cultura más abierta a la autonomía de lo profano, como era la de los propios católicos ilustrados. "Muy bueno es que en todas partes se alabe a Dios, pero cada cosa tiene sus

${ }^{47}$ Método y abusos de la procesión que se hace anualmente en México al beato Felipe de Jesús en el día 5 de febrero. Anexo a la carta del arzobispo de México a Antonio Porcel. 15 de julio de 1805. Sección Audiencia de México. Leg. 2693. AGI, Sevilla, España.

${ }^{48}$ Informe de fray Miguel Vázquez. 10 de agosto de 1803. Testimonio de expediente instruido a consecuencia de la real cédula de S. M. sobre colectación de limosnas para la canonización del beato Felipe de Jesús. Sección Audiencia de México. Leg. 2693. AGI, Sevilla, España.

${ }^{49}$ Informe de fray Miguel Vázquez. 10 de agosto de 1803. Testimonio de expediente instruido a consecuencia de la real cédula de S. M. sobre colectación de limosnas para la canonización del beato Felipe de Jesús. Sección Audiencia de México. Leg. 2693. AgI, Sevilla, España.

\section{()ㅜ(1) $\$$}


destinos", escribía por ejemplo el propio Sosa en otra de sus cartas de $1804 .^{50}$ Esto es, si bien un elemento distintivo de los católicos ilustrados es su crítica de lo profano en lo sagrado, comenzaba también a ser posible ponerle límites a lo religioso. Algunas otras referencias que la prensa de la época hacía del currutaco apuntan a la crítica de ese distanciamiento, aunque sin llegar a presentarlo como un hereje ni un ateo.

Es ya conocido gracias a estudios recientes (López, 2009) el poema satírico El currutaco por alambique, obra de Manuel Gómez (1799), que contaba su fabricación en los infiernos, y que lo describía siempre poniendo el acento en la ambigüedad de su género: "hermafrodita muñequito, cuyo traje y figura, semblante relamido y compostura, [...] obligaba a dudar si es mono o mona. De hembra el cuerpo parece, pero el alma es de macho" (p. 9). Los censores del texto, un padre felipense y el dominico fray Ramón Casaus (futuro arzobispo de Guatemala) no dudaron en alabar una contribución "al exterminio de una moda escandalosa", que era "indigna de la humanidad", según el primero y "exceso indecente, que afemina a los hombres" en los términos del segundo.

Una caracterización muy detallada de las prácticas culturales y religiosas de los currutacos la encontramos en el poema El currutaco temeroso de que lo cojan, primero -al menos hasta donde sabemos-de una serie de al menos seis publicaciones en verso criticándolos aparecidas en el Diario de México entre 1806 y 1808. "En los cafés entran, / los que de prestado / a jugar se alientan, / los que en el bailar / fandango, boleras, / congó, contradanza, / lo hacen sin vergüenza, / los que por las calles / cantando pasean [...] los que van al teatro / sólo a que los vean..." Y en cambio, por lo que hace a religión: "Los que en el Perdón / oyen misa a medias". ${ }^{51}$ A ello podemos agregar su interés por la discusión, que destacaba la Sátira contra los currutacos de marzo de 1808: "Erudito verasle a la violeta, / que habla sin saber lo que está hablando, todo critica, todo lo disputa, / y en todo bulle siempre el locuaz labio". Esos mismos versos reiteran su incipiente toma de distancia del culto católico: "si oye misa, es en pie y se santigua / con rapidez.... ${ }^{52}$

No era raro que se utilizaran estas representaciones de lo que se estimaba como desviaciones del correcto comportamiento de género en las pro-

${ }^{50}$ Carta de Francisco Sosa a José Antonio Caballero. 26 de febrero de 1804. Sección Audiencia de México. Leg. 1892. AgI, Sevilla, España.

51 Diario de México, 1 de enero de 1806, t. 2, núm. 93, p. 1.

52 Diario de México, 6 de marzo de 1808, t. viII, núm. 889, pp. 162-163.

\section{()(1) $(3$}


cesiones religiosas, asociándolas al diablo, y desde luego, usándolas para criticarlas. Un caso célebre es el de la tarasca madrileña que abría la procesión de Corpus Christi de Madrid, y en la que se incluían representaciones de la "petimetra", la mujer vanidosa, tan precisas que llegaron paradójicamente a constituirse en ejemplo a seguir para las interesadas en la moda (Molina, 2013, pp. 382-384). La petimetra de la tarasca del Corpus madrileño y el currutaco del acompañamiento del beato Felipe de Jesús en México, nos recuerdan así que también los estereotipos de género eran movilizados en los combates religiosos y culturales del siglo xviII. Esto es, sin duda el festejo del mártir mexicano era "popular", como ya se ha señalado en la historiografía, pero era también parte activa de enfrentamientos entre las elites al interior del catolicismo novohispano.

La crítica de Sosa planteaba así el problema de si la procesión debía seguir siendo escenario para la corrección de las costumbres o sólo teatro de la devoción. Al menos en la parte novohispana del procedimiento se impuso lo primero, y el arzobispo Lizana debió de ceder. En un segundo informe del 6 de marzo de 1806 declaró: "las imágenes de la procesión son conformes al espíritu de la Iglesia, y excitan a devoción, piedad e imitación del beato". ${ }^{53}$ Así, los pasos lograron sobrevivir a la crítica de Sosa y a una resolución en contrario del Consejo de España e Indias de 1811, e incluso trascendieron más allá de la independencia. Entonces, sin embargo, reaparecieron críticas puntuales al respecto, pero en la prensa, de nueva cuenta destacando el paso en que aparecía representado el diablo. El Águila Mexicana dio cuenta de la ya fiesta nacional del 5 de febrero de 1826. Los editores de este periódico de liberales moderados no dejaron de advertir: "decimos con franqueza que la creeríamos más solemne y más digna de la majestad del asunto". La crítica liberal recuperó la propuesta del proyectista ilustrado: "Con una sola efigie bastaría, excluyendo principalmente el paso del diablo." ${ }^{4}$

No era raro que la representación del mal tuviera un papel importante, toda vez que el gran tema religioso que se explotaba de la vida del beato en esos primeros años del siglo xix era su conversión. En efecto, la fiesta tenía también su lado ejemplarizante, según insistieron los defensores de los pasos. Aunque es difícil probarlo a cabalidad, ya la profesora Zárate (2002,

${ }^{53}$ Informe del arzobispo de México. 6 de marzo de 1806. Testimonio de expediente instruido a consecuencia de la real cédula de S. M. sobre colectación de limosnas para la canonización del beato Felipe de Jesús. Sección Audiencia de México. Leg. 2693. AgI, Sevilla, España.

${ }^{54}$ Solemnidades. El Águila Mejicana, 7 de febrero de 1826, año III, núm. 229, p. 2.

\section{()(1) $\$$}


p. 363) suponía alguna relación entre las imágenes de la procesión y la serie de grabados publicada en 1801 por José María Montes de Oca titulada Vida de San Felipe de Jesús. Protomártir del Japón y patrón de su patria. Comparten ciertamente la insistencia en la tentación, la conversión y la penitencia del fraile, bien que el demonio no aparece vestido de currutaco en los grabados. De esa serie de 30 imágenes, de la sexta a la décimocuarta se contaba todo ese proceso de transformación del futuro mártir: su tentación siendo ya novicio, su embarque a Manila como comerciante, su conversión y segunda toma del hábito, la profesión definitiva, el cambio de nombre abandonando su prestigio familiar, y su entrega a la caridad, la penitencia, la oración y sujeción a un prelado particular, testimonio de su "humildad y negación de sí mismo".

Algo semejante puede decirse de la Devoción para el día cinco impresa en 1812 por el bachiller José Manuel Sartorio, que incluía doce himnos, uno para cada día cinco de mes, usados ya desde 1807 (se publicaron en el Diario de México) y para los que compuso la música José Manuel Delgado, y que justo comenzaban, no con su nacimiento, sino con su conversión y terminaban con sus milagros ya fallecido (Sartorio, 1812, pp. 7-34). El primero de esos himnos, que debía rezarse el 5 de febrero, relataba con detalle: "La santa vestidura / dejó con veleidad / y tras de sus pasiones / ciego corriendo va." Ya el año anterior, el mismo padre Sartorio había publicado en el mismo Diario de México una octava cantándole a otro momento de la vida profana del todavía Felipe de las Casas: la despedida de su padre por su embarque a Manila, ${ }^{55}$ que completó con una justificación muy clara de la memoria de este pasaje: "Tú que esta imagen ahora estás mirando / ¿Dudas rendirle culto religioso, / porque te lo presente en tiempo, cuando / aun no lo había hecho la virtud famoso? / No dudes, no; pues ya ahora está gozando / su original del galardón glorioso; / ni otro Felipe ha sido el de esta historia / que aquel Felipe, que hoy está en la gloria." 56

Un soneto más se publicó en las páginas del mismo Diario el 5 de febrero de 1807, junto con una extensa justificación de la procesión, firmada bajo el seudónimo de Jorge Smir Eduaijavea, retomando, por cierto, varios de los argumentos y ejemplos que en su momento utilizó Ladrón de Guevara. En principio, no dudaba en llamarla "devoto acompañamiento" y en asegurar que las representaciones de la vida del protomártir se distinguían por su "mucha propiedad y decoro". En seguida, recordaba la antigüedad de

55 Diario de México, 3 de febrero de 1806, t. 2, núm. 126, p. 133.

56 Diario de México, 4 de febrero de 1806, t. 2, núm. 126, p. 137.

\section{()(1) $(3$}


la veneración de imágenes, e insistía sobre todo en su papel memorial "para recordar e instruir principalmente al pueblo sobre los hechos de las vidas de los santos", señalando en fin un punto fundamental: la emoción. Las imágenes generaban "la mayor devoción y ternura", concluyendo además con la misma idea de la octava de Sartorio: la adoración se encamina a su prototipo no importando la forma específica de la imagen, respondiendo así a Sosa y su insistencia en las representaciones sólo del instante del martirio. ${ }^{57}$

Andando el tiempo, sin embargo, es verdad que este énfasis habría de ir disminuyendo. Es interesante comparar, ya para finalizar, la edición de la Devoción de Sartorio de 1812 con la que hizo el gremio de los plateros capitalinos -fieles al que era también su santo patrono particular- en 1852, y que incluía un Compendio de la vida del protomártir (Compendio, 1852, pp. $\mathrm{I}$-X) seguida de la Devoción pero con importantes modificaciones. Ambas iniciaban con un "acto de contrición", pero la de 1812 recordaba a las grandes conversiones neotestamentarias (María Magdalena, Mateo, Pablo de Tarso), la de San Agustín de Hipona, y claro, la de Felipe de las Casas, "gloriosísimos triunfos" de la piedad divina, mientras que en 1852 se trataba de un acto más breve y exclusivamente centrado en el arrepentimiento de quien lo presentaba. Asimismo, esta última edición reemplazaba con una oración a la Virgen (Compendio, 1852, p. 2) la que en 1812 estaba dedicada a Dios mismo, y que comenzaba recordando el designio providencial de la etapa profana de la vida de Felipe, cuando "llenásteis de amarguras sus pasatiempos y delicias, a fin de que hostigado de los momentáneos placeres, corriese sólo en busca de la sólida felicidad" (Sartorio, 1812, p. 2). Los himnos de Sartorio y de Delgado fueron eliminados en beneficio de un listado de indulgencias, en que se incluían algunas concedidas en fecha relativamente reciente por el obispo de Monterrey, José María de Jesús Belauzarán (Compendio, 1852, pp. 7-10). En fin, en el propio relato de la vida del beato su etapa profana había perdido sentido trascendental, y los plateros se veían obligados a un retrato que insistía en su moderación: lejos de ser un "desenfrenado libertino", afirmaban "no constan los grandes desórdenes que se le atribuyen" (Compendio, 1852, p. III).

Desde nuestra perspectiva, pues, no puede soslayarse que ese "acompañamiento político" de principios del siglo xIX, era también parte de un cierto proyecto clerical, de Ladrón de Guevara y de Sartorio, compartido por los franciscanos, para combatir los males específicos, de orden moral, que

57 Diario de México, 5 de febrero de 1807, t. 5, núm. 493, pp. 139-142.

\section{()ㅜ(1) $\$$}


encontraban en la sociedad de su tiempo, brindando un ejemplo, el de Felipe de Jesús. Sin embargo, es difícil decir que el "gloriosísimo campeón de las milicias cristianas" de la oración de 1852 hubiera sido el triunfador también de ese combate. Antes bien, de manera paradójica, se ganó la devoción de uno de los publicistas más críticos con el catolicismo de las primeras décadas del siglo, José Joaquín Fernández de Lizardi. En sus versos, y en las oraciones que distribuían los plateros a mediados del siglo, el protomártir era sobre todo invocado como protector no tan sólo de los artesanos plateros sino en general de sus compatriotas, quienes habían de pedirle "vuelve los ojos a esta tu patria, y compadecido de sus necesidades, alcánzale el remedio de ellas" (Compendio, 1852, p. 3). Esto es, también en su dimensión propiamente religiosa, Felipe de Jesús terminó más bien definido por su papel político de abogado celestial de la nación mexicana.

\section{COMENTARIOS FINALES}

La gestión del prebendado Joaquín José Ladrón de Guevara como comisionado de la canonización y fiesta del beato Felipe de Jesús nos ha permitido analizar algunas de las transformaciones y continuidades de este tipo de organización festiva entre finales del antiguo régimen y las primeras décadas del liberalismo en el primer tercio del siglo xix. Ante todo, lo más evidente es el casi abandono de la causa de canonización en beneficio de la fiesta, que pasa de ser del patrono de la ciudad de México, a nacional y del protomártir mexicano. Además, hemos encontrado cambios en las maneras de allegarse recursos, pero sobre todo en los principios que regían esas prácticas, en el marco de una continua falta de apoyo popular a la causa de canonización; cambios en la definición de la fiesta, de pública a nacional, manteniendo los ritos y cortesías una función política; cambios en fin en los mensajes religiosos que debía transmitir la fiesta, del combate a la cultura profana a la protección de los hijos de una misma nación moderna. Desde luego, las opiniones de Francisco Sosa primero, de los liberales después, incluidos diputados y senadores, así como publicistas, producto del proceso de secularización, han resultado decisivas en esta historia. La causa y la fiesta estuvieron marcadas por las nacientes críticas modernas expresadas por los ilustrados y por la opinión pública.

Ahora bien, aunque con sus reducidas limosnas hemos tenido algún indicio, es difícil saber qué tanto éxito tenía realmente el protomártir más

\section{()(1) $(9$}


allá de los fastos de la fiesta pública y nacional. Para tener una idea hemos revisado los libros de bautizos de la parroquia del Sagrario de México desde 1793 hasta $1833 .^{58}$ El nombre de Felipe de Jesús era más frecuente entre los españoles (101) que entre las castas (29) durante la época en que se llevaban libros separados, es decir, en los primeros 27 años de nuestro recuento hasta 1819. En realidad sólo empieza a aparecer con más frecuencia a partir de 1824, con poco menos de diez bautizos anuales: 96 en total entre 1824 y 1833, 115 si incluimos a los niños expósitos, siendo que todas las categorías confundidas hacen un total de 191 entre 1793 y 1823, poco más de seis en promedio anualmente. Si el trabajo de Ladrón de Guevara no logró llevar a Felipe de Jesús a la santidad, pareciera que el ascenso de la fiesta a nacional y de la asociación del protomártir con la nación, a pesar de reforzar el aspecto político del beato y su fiesta, podrían haber contribuido, así sea levemente, al reconocimiento que los habitantes de la parroquia principal de la ciudad tenían de él como protector.

\section{LISTA DE REFERENCIAS}

Boutry, P. (1986). Prêtres et paroisses au pays du curé d'Ars. París: Éditions du Cerf.

Callahan, W. (1989). Iglesia, poder y sociedad en España, 1750-1874. Madrid: Nerea.

Cañeque, A. (2004). De sillas y almohadones o de la naturaleza ritual del poder en la Nueva España de los siglos XVI y XVII. Revista de Indias, 232, 609-634. DOI:10.3989/ revindias.2004.i232.427

Carbajal, D. (2016). Cuerpos profanos o fondos sagrados. La reforma de las cofradías en Nueva España y Sevilla durante el Siglo de las Luces. Lagos de Moreno: CULagos Ediciones-Universidad de Guadalajara.

Compendio de la vida del protomártir del Japón San Felipe de Jesús, patrón de México su patria y devoción consagrada a celebrar su memoria el día cinco de cada mes (1852). México: Imprenta de Lovis Morales.

Connaughton, B. (2010). Entre la voz de Dios y el llamado de la patria. Religión, identidad y ciudadanía en México, siglo xIx. México: Fondo de Cultura Económica/Universidad Autónoma Metropolitana-unidad Iztapalapa.

${ }^{58}$ Family Search, México, Distrito Federal, registros parroquiales y diocesanos, 15141970. Asunción Sagrario Metropolitano. Libros de bautismos de castas de 1778 a 1794, 1795 a 1811 y 1812 a 1820; Libros de bautismos de españoles de 1792 a 1798, 1799 a 1803, 1804 a 1808 , 1809 a 1813,1814 a 1815, 1817 a 1819, 1820 a 1823, 1824 a 1827, 1827 a 1830, 1830 a 1833; Libros de bautismos de niños expósitos 1782 a 1795, 1796 a 1814 y 1815 a 1833.

\section{()(1) $\$$}


Conover, C. (2011). Saintly Biography and the cult of San Felipe de Jesús in Mexico City, 1597-1697. The Americas, 64(4), 441-466. Dor: http://dx.doi.org/10.1017/ S0003161500000328

Corbin, A. (1994). Préface. En A. Corbin, N. Gérôme y D. Tartakowsky (dirs.), Les usages politiques des fêtes aux 19e-20e siècles (pp. 7-11). París: Publications de la Sorbonne.

Dávila, R. (1828). Taller de cohetería. Diálogos críticos entre un cohetero y un tamborilero. México: Imprenta de Alejandro Valdés.

Di Stefano, R. (2004). El púlpito y la plaza. Clero, sociedad y política de la monarquía católica a la república rosista. Buenos Aires: Siglo XXI.

Dublán, M. y Lozano, J. M. (1876). Legislación mexicana o colección completa de las disposiciones legislativas expedidas desde la independencia de la república. México: Imprenta del Comercio.

Fernández de Lizardi, J. J. (1821). Memorial de la madre de San Felipe de Jesús presentado en cabildo el viernes 26 de enero del año de 1629. México: Oficina de J. M. Benavente y socios.

Fernández de Lizardi, J. J. (1963). Obras. Vol. I. México: Universidad Nacional Autónoma de México.

García, A. (1904). El libro de mis recuerdos: narraciones históricas, anecdóticas y costumbres mexicanas anteriores al actual estado social. México: Imprenta de Arturo García Cubas, Hermanos Sucesores.

Hale, C. (1999). El liberalismo mexicano en la época de Mora. México: Siglo XXI Editores. Lempérière, A. (2003). De la república corporativa a la nación moderna. México (1821-1860). En F.-X. Guerra y A. Annino (coords.), Inventando la nación. Iberoamérica siglo XIX (pp. 316-346). México: Fondo de Cultura Económica.

Lempérière, A. (2004). Entre Dieu et le roi: la république. Mexico, XVI-XIX siècles. París: Les Belles Lettres.

López, B. (2009). "Los currutacos herrados" y "El currutaco por alambique": Agudeza verbal y crítica social en dos textos satíricos del siglo xviII. En J. P. Buxó (ed.), Unidad y sentido de la literatura novohispana (pp. 445-459). México: Universidad Nacional Autónoma de México.

Marroquí, J. M. (1903). La Ciudad de México. T. III. México: Tipografía y Litografía "La Europea" de J. Aguilar Verea y Compañía.

Molina, A. (2013). Mujeres y hombres en la España ilustrada. Identidad, género y visualidad. Madrid: Cátedra.

Montes de Oca, J. M. (1801). Vida de San Felipe de Jesús. Protomártir del Japón y patrón de su patria. México: José María Montes de Oca impresor.

\section{()(1) $(2$}


Moro, R. (2012). ¿Una práctica poco visible? La demanda de limosnas "indígena” en la Nueva España del siglo xviII (Arzobispado de México). Estudios de Historia Novohispana, 46, 115-172. Recuperado de http://www.revistas.unam.mx/index.php/ ehn/article/view/32490

Ozouf, M. (1976). La fête révolutionnaire, 1789-1799. París: Gallimard.

Sartorio, J. M. (1812). Devoción para el día cinco dedicado a celebrar la memoria e implorar la protección del glorioso protomártir del Japón Felipe de Jesús. México: Imprenta de Doña María Fernández de Jáuregui.

Serrano, S. (2008) ¿Qué hacer con Dios en la República? Política y secularización en Chile (1845-1885). Santiago: Fondo de Cultura Económica.

Terán, M. (2006). De nación española a federación mexicana. La opinión pública en la formación de la nación. Mexican Studies/Estudios Mexicanos, 22(2), 251-274. Recuperado de http://www.jstor.org/stable/10.1525/msem.2006.22.2.251

Turrent, I. (2013). Rito, música y poder en la catedral metropolitana. México, 1790-1810. México: Fondo de Cultura Económica.

Voekel, P. (2002). Alone before God. The religious origins of modernity in Mexico. Durham/Londres: Duke University Press.

Zárate Toscano, V. (2000), El proyectismo en las postrimerías del virreinato. En C. Yuste (coord.), La diversidad del siglo XVIII novohispano. Homenaje a Roberto Moreno de los Arcos (pp. 229-250). México: unAm.

Zárate Toscano, V. (2002). Las fiestas en honor de Felipe de Jesús, santo novohispano. En E. França Paiva y C. M. Junho Anastasia (orgs.), O trabalho mestiço: Maneiras de pensar e formas de viver - seculos XVI a XIX (pp. 357-375). São Paulo: Annablume/ Posgraduaçao Historia Universidade Federal de Minas Gerais.

Zárate Toscano, V. (2004). La conformación de un calendario festivo en México en el siglo XIX. En A. Salmerón y E. Pani (coords.), Conceptualizar lo que se ve. François-Xavier Guerra historiador. Homenaje (pp. 182-214). México: Instituto Mora. Zárate Toscano, V. (2005). El cielo se llena de santos mexicanos. Nuevo Mundo Mundos Nuevos. Dor: 10.4000/nuevomundo.215

\section{(이)(1) $(2$}

